Iğdır Üniversitesi Fen Bilimleri Enstitüsü Dergisi, 11(3): 2051-2061, 2021

Journal of the Institute of Science and Technology, 11(3): 2051-2061, 2021

Gıda Mühendisliği / Food Engineering

ISSN: 2146-0574, eISSN: 2536-4618

DOI: 10.21597/jist.873725

Araştırma Makalesi / Research Article

Geliș tarihi / Received: 03-02-2021

Kabul tarihi / Accepted: 10-04-2021

Atıf İçin: Odunkıran, A. Zor, M., Şengül, M.2021. Edirne’de Geleneksel Olarak Üretilen Badem Ezmesinin Bazı Kalite Özellikleri. Iğdır Üniversitesi Fen Bilimleri Enstitüsü Dergisi, 11(2): 2051-2061.

To Cite: Odunkiran, A., Zor, M., Şengul, M.2021. Some Qualıty Characterıstıcs Of Almond Paste Produced Tradıtıonally In Edirne. Journal of the Institute of Science and Technology, 11(2): 2051-2061.

\title{
Edirne’de Geleneksel Olarak Üretilen Badem Ezmesinin Bazı Kalite Özellikleri
}

\section{Arzu ODUNKIRAN ${ }^{1} *$, Melek ZOR ${ }^{2}$ Memnune ȘENGÜL ${ }^{3}$}

ÖZET: Badem ezmesi, badem, şeker ve az miktarda sudan geleneksel ve endüstriyel olarak üretilen ekonomik açıdan değerli bir üründür. Saray mutfağından çıkıp günümüze kadar farklı katkılar ve yöntemlerle üretilen badem ezmesi, günümüzde özellikle Edirne'de birçok yerel işletme tarafından yaygın bir şekilde geleneksel olarak üretilmekte ve gastronomi kültürünün yaygın bir parçasını oluşturmaktadır. Bu çalışma Edirne'de beş farklı işletme tarafindan geleneksel yöntemle üretilmiş badem ezmelerinin bazı fiziksel ve kimyasal özelliklerinin belirlenmesine yönelik yapılmıștır. Örneklerin nem miktarı \%6.31-9.09, toplam kül miktarları \%3.03-3.88, titrasyon asitliği \%1.40-1.72, protein miktarları \%9.45-14.87, HMF miktarları 0-0.007 mg kg ${ }^{-1}, \mathrm{pH}$ değerleri 5.375.95, $\mathrm{L}^{*}$ değerleri 64.77-73.26, $\mathrm{a}^{*}$ değerleri $(-1.14)-(-0.48)$ ve $\mathrm{b}^{*}$ değerleri $(+20.03)-(+22.21)$ olarak tespit edilmiştir. Örneklerin $\mathrm{DPPH}^{*}$ ve $\mathrm{ABTS}^{++}$radikali giderme aktiviteleri $\left(\mathrm{IC}_{50}\right)$, toplam fenolik madde miktarları sırasıyla; 81.73-93.77 $\mu \mathrm{g} \mathrm{mL}^{-1}, 47.64-66.35 \mu \mathrm{g} \mathrm{mL}^{-1}, 17.44-32.22 \mathrm{mg} \mathrm{GAE} \mathrm{g}^{-1}$ olarak tespit edilmiştir. Örneklerin mineral madde kompozisyonu ICP-MS ile belirlenmiştir. Analizi yapılan badem ezmesi örneklerinin tümünde en yüksek miktarda Potasyum (K) minerali tespit edilmiş olup, bu mineral miktarı $22770.62-39569.68 \mathrm{mg} \mathrm{kg}^{-1} \mathrm{olarak}$ belirlenmiştir. Potasyumu takiben sırasiyla fosfor (19307.9-27418.58 $\mathrm{mg} \mathrm{kg}^{-1}$ ) ve magnezyum (10146.04$15424.03 \mathrm{mg} \mathrm{kg}^{-1}$ ) badem ezmelerinde en yüksek olarak belirlenen mineral maddelerdir.

Anahtar Kelimeler: Antioksidan aktivite, badem ezmesi, ICP-MS, mineral içeriği, toplam fenolik madde

\section{Some Quality Characteristics of Almond Paste Produced Traditionally in Edirne}

ABSTRACT: Almond paste is an economically valuable product produced traditionally and industrially from almond, sugar and small amounts of water. Almond paste, which came out of the palace kitchen and produced with different additives and methods until today, is widely produced traditionally by many local food factory, especially in Edirne, and forms a common part of the gastronomic culture. In this study, some physical and chemical properties of almond paste produced by traditional method in five different food factory in Edirne were determined. The humidity as 6.31-9.09\%, total ash as 3.03-3.88\%, titration acidity as $1.40-1.72 \%$, protein as $9.45-$ $14.87 \%$, hydroxymethylfurfural amounts as $0-0.007 \mathrm{mg} \mathrm{kg}^{-1}, \mathrm{pH}$ as $5.37-5.95, \mathrm{~L}^{*}$ as $64.77-73.26$, a* as (-1.14)(- 0.48), $\mathrm{b}^{*}$ values as $(+20.03)-(+22.21)$, of the samples. DPPH $^{*}$ and ABTS $^{\cdot+}$ radical scavenging activity (IC 50 value) and total phenolic content of samples were determined, 81.73-93.77 $\mu \mathrm{g} \mathrm{mL}^{-1}$, 47.64-66.35 $\mu \mathrm{g} \mathrm{mL}$ and 17.44-32.22 mg GAE g ${ }^{-1}$, respectively. The mineral composition of the samples was determined by ICP-MS. Potassium was determined as the highest mineral in all of the different almond paste samples analyzed, ranging between 22770.62-39569.68 mg kg${ }^{-1}$. After potassium, phosphorus (19307.9-27418.58 mg kg-1) and magnesium (10146.04-15424.03 $\mathrm{mg} \mathrm{kg}^{-1}$ ) were the next highest mineral substances determined in the almond paste samples.

Keywords: antioxidant activity, almond paste, ICP-MS, mineral content, total phenolic content

${ }^{1}$ Arzu ODUNKIRAN (Orcid ID:0000-0002-5795-218X), Ağrı İbrahim Çeçen Üniversitesi, Uygulamalı Bilimler Yüksekokulu, Gastronomi Bölümü, Ağrı

${ }^{2}$ Melek ZOR (Orcid ID:0000-0002-6455-8594), Iğdır Üniversitesi, Iğdır Meslek Yüksekokulu, Otel Lokanta ve İkram Hizmetleri Bölümü, Iğdır

${ }^{3}$ Memnune ŞENGÜL (물 ID:0000-0003-3909-2523), Atatürk Üniversitesi, Ziraat Fakültesi, Gıda Mühendisliği Bölümü, Erzurum, Türkiye

*Sorumlu Yazar/Corresponding Author: Arzu ODUNKIRAN, e-mail: arzu.odunkiran@igdir.edu.tr 
Edirne'de Geleneksel Olarak Üretilen Badem Ezmesinin Bazı Kalite Özellikleri

\section{GİRIS}

Badem, fıstık, fındık, kaju gibi kuruyemişler, yüksek doymamış yağ asidi içeriği ve sağlık açısından faydaları (kan basıncını düşürme, kalp krizi ve diyabet riskini azaltma gibi) nedeniyle araştırmacılar ve son zamanlarda gıda pazarlamacıları ve tüketiciler tarafindan oldukça fazla ilgi görmektedirler. Bu kuruyemişler, çikolata, kek, dondurma, tatlı gibi ürünlere çiğ veya kavrulmuş halde, organoleptik özellikleri geliştirmek amacıyla oldukça yaygın olarak ilave edilmektedirler (King ve ark., 2008; Lin ve ark., 2012; Balta, 2013).

Rosaceae familyasının Prunus cinsine ait olan badem (P. amygdalus Batch., sinonim. P. dulcis Miller.), Türkiye'nin, Marmara ve Akdeniz bölgelerinde yetişebilen çok yıllık bir bitkidir. Yapılan çalışmalarda badem ve ürünlerinin içerdiği yağ asitleri, $\alpha$-tokoferol, flavonoid, gıda lifi ve yüksek protein sayesinde sağlik üzerine olumlu etkilerinin olduğu belirlenmiştir (Aydin, 2003; Jambazian ve ark., 2005; Kornsteiner ve ark., 2006; Kurlandsky ve Stote, 2006). Kuruyemişlerden özellikle badem ve fıstıkların yaklaşık 10.000-12.000 yıl önce avcı toplumlarının yerleşik köylerinin oluşmasını sağlayan ve önemli yeni bir gelişme olan "tarım” kavramının ortaya çıkmasında önemli bir faktör olduğuna inanılmaktadır (Cunningham, 1999).

Ticaret yollarında baharatlar, yağlar ve ipekler ile işlem görmüş olan badem ve bademden üretilen ürünler geçmişten günümüze kadar önemini korumaya devam etmiştir. Bademden üretilen birçok ezme tipi ürün bulunmasına rağmen, badem ezmesi ve marzipan (Almanya, Danimarka, İngiltere, İsveç gibi Avrupa ülkelerinde badem ezmesinden yapılan şekerleme) gibi ürünler ekonomik değere sahiptir. Badem ezmesinin geçmişinin Ortadoğu'ya dayandığı bilinmektedir. Arapların VII. yy'da İspanya'yı işgal ettiğinde yanlarında badem ve narenciye taşımış oldukları ve böylece badem ezmesinin dünya üzerinde yayılımının gerçekleşmesini sağladıkları bilinmektedir (Cunningham, 1999).

En sevilen badem ürünlerinden biri olan badem ezmesi, basit olarak bademin ögütülmesi, ardından glikoz şurubu veya şeker karışımı ilavesiyle elde edilen bir üründür (Faid ve ark., 1995). Enerji sağlamada oldukça önemli bir kaynak olan badem ezmesinin 100 gramının 458 kcal enerji sağladığı ve günlük kalori ihtiyacının 1/5'ini karşıladığı bildirilmektedir (Çapanoğlu, 2002).

Badem ezmesinin geleneksel ve endüstriyel olarak iki farklı şekilde üretimi söz konusudur. Türkiye'de üretilen badem ezmelerinin temel üretim aşamaları, beyazlatma ve bademden kabuk uzaklaştırılması, şekerle karıştırılması ve son olarak özel bir değirmen kullanılarak karışımın öğütülmesi ile gerçekleştirilmektedir. Üretim için kuru veya daha önceden nemlendirilmiş bademler kullanılabilmektedir. Kurutulmuş taneler kullanılacak ise, badem tanelerinin üretimden önce tekrar nemlendirilmesini sağlayan bir proses gerekmektedir. Geleneksel üretimde bademler ve şeker beraber buhar enjeksiyonlu bir makinaya konularak $1500 \mathrm{rpm}$ gibi düşük bir hızda ve kısa bir sürede buhar uygulamasıyla öğütülme işlemine tabi tutulmakta ve ardından badem ezmesini mikrobiyolojik olarak güvenilir hale getirebilmek için $88{ }^{\circ} \mathrm{C}$ 'lik bir sıcaklığa ulaşması sağlanmaktadır. Ardından ezmeye hemen bir soğutma işlemi uygulanıp geleneksel olarak elde edilen karışım elle yoğurulup, şekil verilerek ambalajlanmaktadır. Son üründeki nem miktarının minimum seviyede tutulması için nem miktarının önceden belirlenmesi gerekmektedir. Bu minimum nem miktarı, birçok faktöre bağlı olmakla beraber hammaddenin değişik şekillerde yıkanması ve hazırlanmasıyla da farklılık göstermektedir. Yapılan işlemlerde kullanılacak hammadde istenilen ürün kalitesi için oldukça önemlidir. Badem ezmesinde istenilen tekstürün elde edilmesi amacıyla öğütme işlemi birkaç kez tekrarlanabilmektedir (Çapanoğlu, 2002).

Endüstriyel olarak üretimlerde ise bir miktar renk maddesi ve aynı zamanda raf ömrünü uzatmak amacıyla katkı maddeleri ilave edilebilmektedir. Bazı ürünlere ise tarçın, lezzet verici bir bileşen olarak 
eklenmektedir. Ancak bazı preparatlarda tarçın eklenemez ve sadece sorbik asit ile korunmaları sağlanır. Badem ezmesi, bazı kek türlerinde olduğu gibi gıdalarda hammadde olarak kullanılabileceği gibi doğrudan tüketim içinde uygun olmaktadır (Faid ve ark., 1995).

Ülkemizde katkı maddesi ilave edilmeden geleneksel olarak üretilen badem ezmelerinin formülasyonu, dokusu, lezzeti ve duyusal özellikleri, endüstriyel olarak üretilen badem ezmesinden oldukça farklıdır. Yüksek yağ içeriği nedeniyle, geleneksel ezmelerin depolama stabilitesi düşüktür ve dolayısıyla raf ömrü daha kısadır. Ürünün raf ömrünü büyük ölçüde oksidatif acılık ve yağ ayrımı belirlemektedir (Cunningham, 1999).

Geçmişten günümüze ulaşan ve saray mutfağı lezzetlerinden biri olan badem ezmesi, günümüzde Edirne'de birçok yerel işletme tarafından yaygın bir şekilde üretilmekte ve gastronomi kültürünün yaygın bir parçasını oluşturmaktadır (Er ve Bardakoğlu, 2005).

Yapılan literatür taramasında badem meyvesinin antioksidan kapasitesi (Pinelo ve ark., 2004; Wijeratne ve ark., 2006; Monagas ve ark., 2007; Sfahlan ve ark., 2009; Esfahlan ve ark., 2010; Safarian ve ark., 2016; Aslan, 2019; An ve ark., 2020) ve mineral madde kompozisyonu (Çapanoğlu, 2002; Şimşek ve Kızmaz, 2017; Karcık, 2017; Aslan 2019) ile ilgili çalışmaların olduğu; ayrıca badem ezmesinin bazı fizikokimyasal özelliklerinin (Faid ve ark., 1995; Çapanoğlu, 2002; Baiano ve Del Nobile, 2005; Çiftci 2016; Bakla, 2018) ve toplam fenolik madde içeriğinin (Çiftci, 2016; Ciftci ve Ozilgen 2019) belirlendiği sınırlı sayıda çalışmanın mevcut olduğu, ancak badem ezmelerinin HMF (Hidroksi metil furfural) miktarı ve antioksidan aktivitesi ile ilgili herhangi bir çalışmaya rastlanmamıştır. Bu yüzden bu çalışmada Edirne ilinde yaygın olarak üretilen ve tüketilen bir şekerleme olan badem ezmesi örneklerinin toplam kuru madde, toplam kül, titrasyon asitliği, protein, toplam fenolik madde miktarı, $\mathrm{pH}, \mathrm{L}^{*}, \mathrm{a}^{*}, \mathrm{~b}^{*}$ değerleri gibi fizikokimyasal özelliklerinin yanı sıra HMF miktarı, antioksidan aktivitesi ve mineral madde kompozisyonunun tespit edilmesi amaçlanmıştır.

\section{MATERYAL VE METOT}

\section{Materyal}

Araştırmada, Edirne'de beş farklı işletmede geleneksel yöntemle üretilmiş badem ezmeleri aynı tarihte alınmış ve materyal olarak kullanılmıştır. Badem ezmeleri, analizler sırasında serin $\left(15 \pm 2{ }^{\circ} \mathrm{C}\right)$ ve karanlık bir ortamda paketli bir şekilde tutulmuş ve 1 ay içerisinde tüm analizler bitirilmiştir. Badem ezmesi örnekleri 1'den 5'e kadar numaralandırılmıştır. Çalışmada kullanılan kimyasal maddeler analitik saflıkta olup, Sigma-Aldrich (St. Louis, MO, USA)'den temin edilmiştir.

\section{Yöntem}

\section{Fizikokimyasal analizler}

Örneklerin nem, toplam kül ve titrasyon asitliği (oleik asit cinsinden), HMF miktarı ve pH değeri (Cemeroğlu, 2013) tespit edilmiştir. Kjeldahl yöntemi ile belirlenen toplam azot miktarı 6.25 faktörü ile çarpılarak örneklerin protein miktarı belirlenmiştir (Kurt ve ark., 1999; Şimşek ve Kızmaz 2017; Yıldırım ve ark. 2008). Renk yoğunluğu Minolta kolorimetre (Chroma Meter, CR- 200, Japan) cihazı ile ölçülmüştür. Badem ezmeleri beyaz bir zemin üzerine konulmuş ve kalibre edilen kolorimetre ile ölçüm yapılmıştır. CIELAB renk skalasına göre $L^{*}$ değerleri parlaklık $(0=$ siyah, 100=beyaz) (koyuluk/açıklık), a* değeri +60 ve 0 aralığında kırmızı ve 0 ve -60 aralığında yeşil- (+a kırmızı, -a yeşil), b* değeri +60 ve 0 aralığında sarı, 0 ve -60 aralığında mavi (+b sarı, -b mavi) renk yoğunluklarını gösteren değerlerdir (Luo, 2006; Polatoğlu, 2013).

\section{Toplam fenolik madde ve antioksidan aktivite tayini için ekstrakt hazırlanması}

Ekstraksiyon işlemi için badem ezmesi örnekleri etanol ve su (90:10 mL) çözgeni ile çalkalamalı karıştırıcıda 250 rpm'de 6 saat süre ile karıştırılmıştır. Daha sonra Whatman No:1 filtre kâğıdından 
süzülerek döner buharlaştırıcıda çözücü uzaklaştırılmıştır. Hazırlanan ekstraktlar $-20^{\circ} \mathrm{C}$ 'de muhafaza edilerek toplam fenolik madde ve antioksidan aktivite tayinlerinde kullanılmıştır (Şengül ve ark., 2012).

\section{Toplam fenolik madde tayini}

Toplam fenolik madde miktarının belirlenmesi için, FCR (Folin- Ciocalteau- Reagent) ayracı ile fenolik bileşiklerin indirgenip oksitlenmesi esasına dayanan yöntemle $760 \mathrm{~nm}$ dalga boyunda spektrofotometre (T60V Spectrometer, PG Instruments) ile absorbans ölçülmüş ve toplam fenolik madde miktarının belirlenmesi için standart olarak gallik asit kullanılmıştır. (Gulcin ve ark., 2002). Standart grafikten elde edilen denklem yardımıyla toplam fenolik madde miktarı gallik asit eşdeğeri ( $\mathrm{mg}$ $\mathrm{GAE} \mathrm{g}^{-1}$ örnek) olarak hesaplanmıştır.

\section{Antioksidan aktivite tayini}

\section{$\mathrm{DPPH}^{\bullet}$ radikal giderme aktivitesi}

$\mathrm{DPPH}^{\bullet}$ radikal giderme aktivitesi tayini $\mathrm{DPPH}^{\bullet}$ (2,2-diphenyl-1-pcyrylhydrazyl) radikali ile antioksidan maddenin hidrojen atomu ile elektronunun yer değiştirmesi sonucu radikalin mor menekşe renginin daha açık sarı ya da renksiz forma indirgenmesi esasına dayanan bir yöntemdir (Rizk ve ark., 2014). Badem ezmesi ekstraktları, 10, 20, $30 \mu \mathrm{g} \mu \mathrm{L}^{-1}$ konsantrasyon olarak deney tüplerine aktarılmış ve son hacim $3 \mathrm{~mL}$ 'ye etanolle tamamlanmıştır. Son olarak $1 \mathrm{~mL} 1 \mathrm{Mm}$ 'lık etanolde hazırlanmış DPPH ${ }^{\bullet}$ çözeltisi ilave edilerek vorteksle karıştırılmış (WiseMix, VM-10) ve karanlıkta 30 dakika inkübasyona birakildiktan sonra $517 \mathrm{~nm}$ dalga boyunda spektrofotometrede (T60V Spectrometer, PG Instruments) ölçüm yapılmıştır (Topdaş, 2018). Kontrol olarak $3 \mathrm{~mL}$ etanol ve $1 \mathrm{~mL}$ DPPH• çözeltisi karışımı kullanılmıştır. Standart antioksidan olarak BHA (Butylated Hydroxyanisole), BHT (Butylated Hydroxyitoluen), troloks ve tokoferol kullanılmıştır. DPPH ${ }^{\bullet}$ radikalini süpürme aktivitesi \% inhibisyonu aşağıdaki eşitlikler kullanılarak saptanmıştır:

$\%$ İnhibisyon $=\left[\left(\mathrm{A}_{\mathrm{DPPH}}-\mathrm{A}_{\text {örnek }}\right) / \mathrm{A}_{\mathrm{DPPH}}\right] \times 100$

$A_{\text {DPPH }}$ Kontrolün absorbans1

Ä̈rnek: Örneğin absorbans1

Farklı konsantrasyonlara karşı hesaplanan \% inhibisyon değerleri ile çizilen grafikten linear regrasyon ile radikalin \%50 inhibisyonuna neden olan konsantrasyonu belirlenmiş ve $\mathrm{IC}_{50}\left(\mu \mathrm{g} \mathrm{mL} \mathrm{m}^{-1}\right)$ olarak ifade edilmiştir (Yılmaz, 2011; Bardakçı, 2017).

\section{ABTS $^{\bullet+}$ radikal giderme aktivitesi}

$\mathrm{ABTS}^{\cdot+}$ radikali yakalama aktivitesinin ölçümü için $0.15 \mathrm{~g}$ ABTS ${ }^{\cdot+}$ (2,2'-Azino-bis(3etilbenzotiyazolin-6-sülfonik asit) tartılarak $100 \mathrm{~mL}$ saf suda çözüldükten sonra $\mathrm{K}_{2} \mathrm{O}_{8} \mathrm{~S}_{2}$ (potasyum peroksi disülfit) ilave edildikten sonra 12-14 saat bekletilerek mavi-yeşil renkli $\mathrm{ABTS}^{\bullet+}$ radikal çözeltisinin hazırlanması sağlanmıştır. Badem ezmesi ekstraktları 10, 20, $30 \mu \mathrm{g}^{-1} \mathrm{k}^{\mathrm{k}}$ onsantrasyonlu olacak şekilde deney tüplerine 3 paralelli olarak aktarılmış ve son hacim etanolle $1.5 \mathrm{~mL}$ 'ye tamamlanmıştır. Daha sonra $0,5 \mathrm{~mL} \mathrm{ABTS}^{\bullet+}$ radikal çözeltisi ilave edilip vorteksle karıştırılarak örnekler karanlıkta 30 dakika bekletilmiştir. Süre sonunda indirgenme $734 \mathrm{~nm}$ dalga boyunda spektrofotometrik olarak ölçülmüştür. Kontrol $1.5 \mathrm{~mL}$ etanol ve $0.5 \mathrm{~mL} \mathrm{ABTS}^{\bullet+}$ çözeltisi ilave edilerek hazırlanmıştır. Standart antioksidan olarak BHA (Butylated Hydroxyanisole), BHT (Butylated Hydroxyitoluen), troloks ve tokoferol kullanılmıştır. ABTS $^{\bullet+}$ radikalini süpürme aktivitesi reaksiyonu yüzde inhibisyonu aşağıdaki eşitlikler kullanılarak saptanmıştır:

$\%$ İnhibisyon= $\left[\left(\mathrm{A}_{\mathrm{ABTS}}-\mathrm{A}_{\text {Örnek }}\right) / \mathrm{A}_{\mathrm{ABTS}}\right] \mathrm{x} 100$

$\mathrm{A}_{\text {ABTS: Kontrolün absorbans1 }}$

Ä̈rnek: Örneğin absorbans1 
Farklı konsantrasyonlara karşı hesaplanan \% inhibisyon değerleri ile çizilen grafikten linear regrasyon ile radikalin \%50 inhibisyonuna neden olan konsantrasyonu belirlenmiş ve $\mathrm{IC}_{50}\left(\mu \mathrm{g} \mathrm{mL}^{-1}\right)$ olarak ifade edilmiştir (Yılmaz, 2011; Karataş, 2014).

\section{ICP-MS ile mineral madde kompozisyonunun belirlenmesi}

Mineral madde analizleri için $0.5 \mathrm{~g}$ örnek tartılmış ve üzerine $8 \mathrm{~mL} \% 65^{\prime}$ lik $\mathrm{HNO}_{3}$ ve $2 \mathrm{~mL}$ $\% 31$ ' lik $\mathrm{H}_{2} \mathrm{O}_{2}$ ilave edilerek 15-20 dakika beklenmiştir. Yaş yakma işlemi mikrodalga esaslı bir sistemde (Milestone connect ETHOS UP mikrodalga) her adımda $200^{\circ} \mathrm{C}$ ve $1800 \mathrm{~W}$ uygulayarak $15^{\prime}$ 'er dakikalık 2 adımda gerçekleştirilmiştir. Yaş yakma işleminden sonra tüp içeriği ultra saf su ile $50 \mathrm{~mL}$ 'ye tamamlanarak membran filtre $(0.45 \mu \mathrm{m})$ ile süzülmüştür. Örnekler $50 \mathrm{~mL}$ 'den $100 \mu 1$ alınarak \%2'lik $\mathrm{HNO}_{3}$ ve \%0.5'lik HCl karışımı ile 10 mL'ye tamamlanarak analiz edilmiştir. İndüktif Eşleşmiş PlazmaKütle Spektrometresi (ICP-MS) ile örneklerde Ca, P, K, Fe, Na, Mg, Al, Mn, Li, Ni, Cu, Zn, As, Se, Cr, $\mathrm{Cd}, \mathrm{Sn}, \mathrm{Hg}$ ve $\mathrm{Pb}$ elementlerinin miktarları tespit edilmiştir (Anonim, 2007).

\section{İstatistiksel analiz}

Araştırmada, analizler 5 farklı badem ezmesinde 3 tekerrürlü olarak gerçekleştirilmiştir. IBM SPSS Statistics Version 20.0 paket programı ile tüm veriler istatistiki olarak değerlendirilmiştir. Sonuçlar ortalama \pm std sapma olarak verilmiştir ve Duncan Çoklu Karşılaştırma Testi ile sonuçlar karşılaştırılmıştır.

\section{BULGULAR VE TARTIŞMA}

\section{Fizikokimyasal Özellikler}

Badem ezmesi örneklerinin bazı fizikokimyasal özellikleri Çizelge 1'de verilmiştir. Badem ezmelerinin saptanan tüm fizikokimyasal özelliklerinin üretimi yapan işletmeye göre istatistiki olarak çok önemli düzeyde $(P<0.01)$ farklı olduğu belirlenmiştir. Badem ezmelerinin nem içeriğinin \%6.31 9.09 arasında değiştiği tespit edilmiştir (Çizelge 1). Badem ezmesinin nem içeriğini Çapanoğlu (2002) \%10.1, Baiano ve Del Nobile (2005) \%9.5-12.0, Çiftci (2016) \%12 ve Bakla (2018) \%6.58 olarak belirlemişlerdir. Yaptığımız araştırmada belirlenen badem ezmesinin nem içeriğinin daha önceki çalışmalarla uyumlu olduğu görülmektedir. Nem miktarının düşük olması, mikrobiyal bozulmanın önlenmesi açısından ve raf ömrünün uzatılması için önemli bir parametredir.

Çizelge 1. Badem ezmesi örneklerinin bazı fizikokimyasal özellikleri

\begin{tabular}{|c|c|c|c|c|c|}
\hline \multirow{2}{*}{ Özellikler } & \multicolumn{5}{|c|}{ Örnekler } \\
\hline & 1 & 2 & 3 & 4 & 5 \\
\hline $\operatorname{Nem}(\%)$ & $6.31 \pm 0.47^{\mathrm{c}^{* *}}$ & $9.09 \pm 0.00^{\mathrm{a}^{* *}}$ & $8.92 \pm 0.17^{\mathrm{a}^{* *}}$ & $8.23 \pm 0.22^{\mathrm{b}^{* *}}$ & $8.40 \pm 0.02^{\mathrm{b}^{* *}}$ \\
\hline Kül (\%) & $3.03 \pm 0.34^{\mathrm{c}^{* *}}$ & $3.88 \pm 0.07^{\mathrm{a}^{* *}}$ & $3.19 \pm 0.30^{\mathrm{bc} * *}$ & $3.48 \pm 0.05^{\mathrm{b}^{* *}}$ & $3.36 \pm 0.08^{\mathrm{bc} * *}$ \\
\hline Protein $(\%)$ & $9.45 \pm 0.03^{\mathrm{d}^{* *}}$ & $12.88 \pm 0.04^{\mathrm{b}^{* *}}$ & $14.87 \pm 0.02^{\mathrm{a}^{* *}}$ & $10.08 \pm 0.08^{\mathrm{c}^{* *}}$ & $10.03 \pm 0.02^{\mathrm{c}^{* *}}$ \\
\hline pH & $5.37 \pm 0.01^{\mathrm{d}^{* *}}$ & $5.81 \pm 0.12^{\mathrm{b}^{* *}}$ & $5.95 \pm 0.02^{\mathrm{a}^{* *}}$ & $5.92 \pm 0.02^{\mathrm{a}^{* *}}$ & $5.51 \pm 0.03^{\mathrm{c}^{* *}}$ \\
\hline Titrasyon Asitliği (\%Oleik Asit) & $1.72 \pm 0.01^{\mathrm{a}^{* *}}$ & $1.71 \pm 0.03^{\mathrm{a}^{* *}}$ & $1.55 \pm 0.01^{\mathrm{b}^{* *}}$ & $1.40 \pm 0.02^{\mathrm{d}^{* *}}$ & $1.44 \pm 0.01^{\mathrm{c}^{* *}}$ \\
\hline $\mathbf{L}^{*}$ & $65.32 \pm 0.01^{\mathrm{c} * *}$ & $64.77 \pm 0.01^{\mathrm{e}^{* *}}$ & $65.28 \pm 0.01^{\mathrm{d}^{* *}}$ & $67.85 \pm 0.03^{b^{* *}}$ & $73.26 \pm 0.01^{\mathrm{a}^{* * *}}$ \\
\hline $\mathbf{a}^{*}$ & $-0.64 \pm 0.02^{\mathrm{c}^{* *}}$ & $-0.64 \pm 0.01^{\mathrm{c}^{* *}}$ & $-1.14 \pm 0.01^{\mathrm{d}^{* *}}$ & $-0.59 \pm 0.01^{\mathrm{b} * *}$ & $-0.48 \pm 0.02^{\mathrm{a}^{* * *}}$ \\
\hline $\mathbf{b}^{*}$ & $20.03 \pm 0.01^{\mathrm{d}^{* *}}$ & $21.20 \pm 0.01^{\mathrm{b}^{* *}}$ & $20.57 \pm 0.01^{\mathrm{c}^{* *}}$ & $22.21 \pm 0.01^{\mathrm{a}^{* *}}$ & $21.22 \pm 0.02^{\mathrm{b}^{* * *}}$ \\
\hline HMF (mg kg $\left.{ }^{-1}\right)$ & ND & ND & ND & $0.007 \pm 0.00^{\mathrm{a}^{* *}}$ & ND \\
\hline
\end{tabular}

**: $P<0.01$ seviyesinde çok önemli; Aynı satırda aynı harfle gösterilen ortalamalar istatistiksel olarak birbirinden farksızdır.; ND: Tespit edilememiştir. 
Yaptığımız çalışmada badem ezmelerinin toplam kül miktarlarının \%3.03-3.88 arasında değiştiği belirlenmiştir (Çizelge 1). Çapanoğlu (2002) badem ezmesinde kül miktarını bizim tespit ettiğimiz miktardan daha düşük olarak (\%1.4) belirlemiştir. Çiftci (2016), benzer şekilde badem ezmesinde kül miktarının \%1.5 olduğunu bildirmiştir. $\mathrm{Bu}$ farklılıkların badem çeşidi, formülasyon ve üretim tekniğinden kaynaklandığı düşünülmektedir.

Daha önce yapılan araştırmalarda badem meyvesinin protein miktarlarının \%4.1-35.1 arasında değiştiği belirlenmiştir (Aydin, 2003; Yıldırım ve ark., 2008; Kodad ve ark., 2013; Çiftci, 2016; Şimşek ve Kızmaz, 2017). Yaptığımız çalışmada badem ezmelerinin protein miktarı \%9.45-14.87 olarak tespit edilmiştir (Çizelge 1). Protein miktarlarında ki farklılıkların sebebinin üretimde farklı firmalarda farklı formülasyonların uygulanmasından kaynaklandığı düşünülmektedir. Çalışmamıza paralel olarak Çapanoğlu (2002) badem ezmesinin protein miktarını \%10.1 olarak rapor etmiştir.

Geleneksel olarak üretilen badem ezmelerinin $\mathrm{pH}$ değerinin 5.37-5.95 arasında olduğu belirlenmiştir (Çizelge 1). Bakla (2018) yüksek hidrostatik basınç uygulanarak üretilen taze badem ezmelerinin pH'sını 6.72 olarak tespit etmiştir. Çalışmamızda ki sonuçlara uyumlu olarak Faid ve ark. (1995)'da badem ezmesinin pH değerini 5.59-5.90 arasında saptamışlardır.

Yaptı̆̆ımız çalışmada badem ezmelerinin titrasyon asitliği oleik asit cinsinden \%1.40-1.72 arasında saptanmıştır (Çizelge 1). Çapanoğlu (2002) yaptığı çalışmada farklı depolama, farklı sıcaklık ve farklı katkılar kullanarak ürettikleri badem ezmelerine ait toplam asitliklerin \%0.23-1.79 arasında değiştiği bildirmişlerdir. Bu çalışmada belirlenen asitlik değerleri Çapanoğlu (2002) ile paralellik göstermektedir.

Isı uygulaması ile badem ezmesinin formülasyonunda bulunan indirgen şekerler ve aminoasitlerin reaksiyonunda ara ürün olarak HMF oluşabileceği düşünülmüş, ancak yapılan analizlerde, badem ezmelerinde yalnızca bir örnekte $0.007 \mathrm{mg} \mathrm{kg}^{-1}$ olarak HMF tespit edilmiş, diğer örneklerde ise tespit edilememiştir (Çizelge 1). Badem ezmelerinde HMF miktarı ile ilgili yapılan literatür taramasında, herhangi bir kaynağa rastlanmamıştır.

Badem ezmelerinin $L^{*}$ değerleri 64.77- 73.26, a* değerleri (-1.14)-(-0.48) ve $b^{*}$ değerleri 20.0322.21 arasında saptanmıştır (Çizelge 1). Bakla (2018) geleneksel ve basınçlı olarak üretilmiş olan badem ezmelerinin $L^{*}$ değerlerini 68.48;67.45, a* değerlerini 2.56;2.73 ve $b^{*}$ değerlerini 22.10;22.25 olarak belirlemiştir. Yaptığımız çalışma ile Bakla (2018)'in çalışmasındaki $L^{*}$ ve $b^{*}$ değerleri paralellik göstermektedir. CIELAB renk skalasına göre $\mathrm{L}^{*}$ değerinin koyuluk/açıklık $(0=$ siyah, 100=beyaz); $+\mathrm{b}$ değerinin de sarı rengin göstergesi olması nedeniyle, badem ezmelerinin $L^{*}$ ve $b^{*}$ değerleri değerlendirildiğinde rengin açık sarıya daha yakın olduğu saptanmıştır.

\section{Toplam Fenolik Madde İçeriği ve Antioksidan Kapasitesi}

Geleneksel yöntemle üretilen badem ezmelerinin toplam fenolik madde miktarlarının 18.96-32.00 mg GAE g ${ }^{-1}$ arasında değiştiği tespit edilmiştir. Badem ezmelerinin toplam fenolik madde miktarlarının üretimi yapan işletmeye göre istatistiki olarak çok önemli düzeyde $(P<0.01)$ farklı olduğu belirlenmiştir (Çizelge 2). Daha önceden bademin (Frison ve Sporns, 2002; Harrison ve Were, 2007) ve badem ezmesinin (Çiftci, 2016) toplam fenolik madde içeriği bazı çalışmalarda belirlenmiştir. Ciftci ve Ozilgen (2019) siyah havuç suyu ilavesiyle üretilen badem ezmesi ile ilgili çalışmada, kontrol gurubu olan sade badem ezmesinde toplam fenolik madde miktarını $95.90 \mathrm{mg}$ GAE $100 \mathrm{~g}^{-1}$ olarak tespit etmiştir. Bu toplam fenolik madde miktarı, bizim bulduğumuz sonuçlardan oldukça düşüktür. Ayrıca, aynı çalışmada badem ezmelerindeki fenolik madde miktarlarının depolama ile azaldığı da rapor edilmiştir. Öte yandan Isfahlan ve ark. (2010) dört badem türü ile yaptıkları çalışmada bademlerde toplam fenolik madde içeriğinin 75.9-122.2 mg GAE g ${ }^{-1}$ arasında olduğunu bildirmişlerdir. İran'ın çeşitli bölgelerinden 18 
genotip bademin gövdesi ve kabukları ayrılarak yapılan bir çalışmada sırasıyla toplam fenolik içerikleri 35.9-166.7 mg GAE g-1 (gövde) 18.4-62.7 mg GAE g-1 (kabuk) olarak belirlendiği rapor edilmiştir (Sfahlan, 2009). Lin ve ark. (2016), bademlerin, fenolik madde miktarı ve antioksidan aktivitesi üzerine kavurma sıcaklığı ve süresinin etkilerini araştırdıkları çalışmalarında; uygulanan farklı kavurma sıcaklık

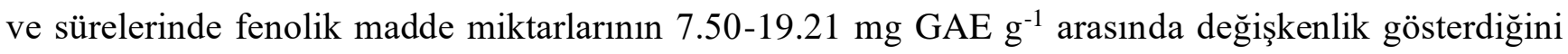
belirlemişlerdir. Bademin toplam fenolik madde miktarlarına bakıldığında badem ezmelerinde daha düşük sonuçlar elde edildiği görülmektedir. Badem ezmelerinin toplam fenolik madde miktarlarında ki farklılıkların işletme şartları ve üretim prosesindeki farklılıklardan kaynaklandığı düşünülmektedir.

Çizelge 2. Badem ezmesi örneklerinin toplam fenolik madde içeriği ve antioksidan aktiviteleri

\begin{tabular}{|c|c|c|c|}
\hline $\begin{array}{l}\text { Örnekler ve } \\
\text { standartlar }\end{array}$ & $\begin{array}{c}\text { Toplam Fenolik Madde (mg } \\
\text { GAE } \text { g }^{-1} \text { ) }\end{array}$ & $\mathrm{DPPH}^{\bullet}\left(\mathrm{IC}_{50}, \mu \mathrm{g} \mathrm{m \textrm {L } ^ { - 1 }}\right)$ & $\operatorname{ABTS}^{++}\left(\mathrm{IC}_{50}, \mu \mathrm{g} \mathrm{mL}^{-1}\right)$ \\
\hline 1 & $18.96 \pm 1.52^{\mathrm{d}^{* *}}$ & $92.84 \pm 0.02^{\mathrm{a}^{* *}}$ & $47.64 \pm 0.02^{\mathrm{e}^{* *}}$ \\
\hline 2 & $32.00 \pm 0.22^{\mathrm{a}^{* *}}$ & $93.77 \pm 0.12^{\mathrm{a}^{* *}}$ & $55.83 \pm 0.01^{\mathrm{c}^{* *}}$ \\
\hline 3 & $27.87 \pm 0.87^{b^{* *}}$ & $81.73 \pm 0.02^{\mathrm{c}^{* *}}$ & $64.47 \pm 0.03^{\mathrm{b}^{* *}}$ \\
\hline 4 & $22.22 \pm 0.87^{\mathrm{c}^{* *}}$ & $93.41 \pm 0.04^{\mathrm{a}^{* *}}$ & $55.18 \pm 0.01^{\mathrm{d}^{* *}}$ \\
\hline 5 & $28.96 \pm 2.39^{\mathrm{b}^{* *}}$ & $88.28 \pm 0.02^{\mathrm{b}^{* * *}}$ & $66.35 \pm 0.01^{\mathrm{a}^{* *}}$ \\
\hline BHA & - & $11.70 \pm 0.01^{\mathrm{e}}$ & $11.59 \pm 0.21^{\mathrm{f}}$ \\
\hline BHT & - & $28.81 \pm 3.34^{\mathrm{d}}$ & $10.53 \pm 0.12^{\mathrm{g}}$ \\
\hline TROLOKS & - & $8.41 \pm 0.82^{\mathrm{f}}$ & $11.65 \pm 0.89^{f}$ \\
\hline TOKOFEROL & - & $10.05 \pm 0.04^{\mathrm{ef}}$ & $11.55 \pm 0.69^{f}$ \\
\hline
\end{tabular}

**: $P<0.01$ seviyesinde çok önemli; Aynı sütunda aynı harfle gösterilen ortalamalar istatistiksel olarak birbirinden farksızdır.

Yaptığımız çalışmada badem ezmesi örneklerinin $\mathrm{DPPH}^{\bullet}$ radikali giderme aktivitesi $\mathrm{IC}_{50}$ değerlerinin 81.73-93.41 $\mu \mathrm{g} \mathrm{mL}^{-1}$ ve $\mathrm{ABTS}^{\cdot+}$ radikali giderme aktivitesi $\mathrm{IC}_{50}$ değerlerinin 47.64-66.35 $\mu \mathrm{g} \mathrm{mL}^{-1}$ arasında değiştiği saptanmıştır. Çalışmada kullanılan antioksidan standartlarına (BHA, BHT, Troloks ve Tokoferol) göre badem ezmelerinin oldukça düşük antioksidan aktivite gösterdikleri belirlenmiştir. Badem ezmelerinin $\mathrm{IC}_{50}\left(\mathrm{DPPH}^{\bullet}\right.$ ve $\left.\mathrm{ABTS}^{\cdot+}\right)$ değerlerinin üretimi yapan işletmeye göre istatistiki olarak çok önemli düzeyde $(P<0.01)$ farklı olduğu belirlenmiştir (Çizelge 2). Yapılan literatür taramasında badem kabuğu, badem gövdesi ve badem zar kabuğunun (kahverengi) yüksek radikal giderme aktivitesi gösterdiği görülmüştür (Pinelo ve ark., 2004; Wijeratne ve ark., 2006; Monagas ve ark., 2007; Sfahlan ve ark., 2009; Esfahlan ve ark., 2010; Safarian ve ark., 2016; An ve ark., 2020). Aslan (2019) yaptığı çalışmada bademlerin $\mathrm{DPPH}^{\bullet}$ radikali giderme aktivitesini (IC 50 değeri) 178.03$276.19 \mu \mathrm{g} \mathrm{mL}^{-1}$ ve $\mathrm{ABTS}^{\bullet+}$ radikali giderme aktivitesini ( $\mathrm{IC}_{50}$ değeri) 28.01-29.73 $\mu \mathrm{g} \mathrm{mL}^{-1}$ olarak bildirmiştir. Badem meyvesine göre $\mathrm{ABTS}^{\cdot+}$ radikali giderme aktivitesi $\mathrm{IC}_{50}$ değerlerinin daha yüksek dolayısı ile daha düşük antioksidan aktivite gösterdiği; bunun sebebinin badem ezmesinde markalara göre değişiklik gösteren ortalama \%40-70 arasında bulunan badem oranının ve üretim sürecinde ulaşılan yaklaşık $80-88^{\circ} \mathrm{C}$ dolaylarındaki 1 sıl işlemin etkisi ile antioksidan bileşiklerde meydana gelen bozulmalardan kaynaklandığı düşünülmektedir. Ancak literatürde katkısız badem ezmesinin antioksidan aktivitesinin belirlendiği bir çalışmaya rastlanmamıştır.

\section{Mineral Madde Kompozisyonu}

Yapılan analizler sonucunda badem ezmesinin potasyum, fosfor, magnezyum ve kalsiyum mineralleri açısından zengin olduğu görülmüştür (Çizelge 3). Tüm örneklerde en yüksek miktarda bulunan mineralin potasyum (22770.62-36659.11 mg kg-1) olduğu saptanmıştır (Çizelge 3). Meyve sebzelerde bol miktarda bulunan potasyum, kanda ozmotik basıncı sodyumla birlikte dengelediğinden dolayı, vücut için elzem olan bir mineraldir (Cemeroğlu, 2018). Potasyum ayrıca kaslarda kasılmayı sağlayan, sinir iletimlerinde önemli rolü olan, vücutta hücre içi asit-baz ve sıvı dengesini sağlayan bir 
mineraldir (Thomas, 2001). Potasyumun insan beslenmesinde günlük alım miktarının $3.5 \mathrm{~g}$ olduğu bildirilmektedir (Çilingir Yeltekin, 2019). $100 \mathrm{~g}$ badem ezmesi tüketimi ile günlük potasyum ihtiyac1 karşılanabilmektedir.

Çizelge 3. Badem ezmesi örneklerinin mineral içerikleri $\left(\mathrm{mg} \mathrm{kg}^{-1}\right)$

\begin{tabular}{|c|c|c|c|c|c|}
\hline \multirow{2}{*}{$\begin{array}{c}\text { Mineral } \\
\text { maddeler }\end{array}$} & \multicolumn{5}{|c|}{ Örnekler } \\
\hline & 1 & 2 & 3 & 4 & 5 \\
\hline Potasyum (K) & $\underset{*}{26302.52 \pm 0.03^{\mathrm{d}^{*}}}$ & $39569.68 \pm 0.12^{\mathrm{a}^{* * *}}$ & $36659.11 \pm 0.01^{\mathrm{b}^{* *}}$ & $36401.05 \pm 0.35^{\mathrm{c}^{* *}}$ & $22770.62 \pm 0.06^{\mathrm{e}^{*}}$ \\
\hline Fosfor (P) & $19075.77 \pm 0.18^{\mathrm{e}^{*}}$ & $26034.21 \pm 0.23^{\mathrm{b}^{* *}}$ & $27418.58 \pm 0.07^{\mathrm{a}^{* *}}$ & $25821.76 \pm 0.06^{\mathrm{c} *}$ & $19307.9 \pm 0.18^{\mathrm{d}^{* *}}$ \\
\hline Magnezyum & $11200.28 \pm 0.06^{\mathrm{d}^{*}}$ & $11864.59 \pm 0.33^{\mathrm{c}^{* *}}$ & $15424.03 \pm 0.06^{\mathrm{a}^{* *}}$ & $12200.96 \pm 0.61^{\mathrm{b} * *}$ & $10146.04 \pm 0.02^{\mathrm{e}^{*}}$ \\
\hline Kalsiyum (Ca) & $2230.90^{*} \pm 0.25^{\mathrm{c}^{* * *}}$ & $2272.68 \pm 0.23^{\mathrm{b}^{* *}}$ & $2643.58 \pm 0.01^{\mathrm{a}^{* *}}$ & $1260.82 \pm 0.37^{\mathrm{e}^{* *}}$ & $1816.89^{*} \pm 0.09^{\mathrm{d}^{* *}}$ \\
\hline Sodyum (Na) & $1944.61 \pm 0.01^{\mathrm{a}^{* *}}$ & $465.49 \pm 0.01^{\mathrm{d}^{* *}}$ & $1387.76 \pm 0.02^{\mathrm{c}^{* *}}$ & $1449.03 \pm 0.01^{\mathrm{b}^{* *}}$ & $220.59 \pm 0.01^{\mathrm{e}^{* *}}$ \\
\hline Demir (Fe) & $415.62 \pm 0.27^{\mathrm{a}^{* *}}$ & $134.29 \pm 0.43^{\mathrm{e}^{* *}}$ & $233.81 \pm 0.57^{\mathrm{b}^{* *}}$ & $202.45 \pm 0.79^{\mathrm{d}^{* *}}$ & $216.67 \pm 0.13^{\mathrm{c}^{* *}}$ \\
\hline Çinko (Zn) & $192.94 \pm 0.04^{b^{* *}}$ & $130.50 \pm 0.37^{\mathrm{d}^{* *}}$ & $672.32 \pm 0.47^{\mathrm{a}^{* *}}$ & $135.64 \pm 0.01^{\mathrm{c}^{* *}}$ & $60.20 \pm 0.06^{\mathrm{e}^{* *}}$ \\
\hline Mangan (Mn) & $63.40 \pm 1.07^{\mathrm{d}^{* *}}$ & $99.61 \pm 0.99^{\mathrm{b}^{* * *}}$ & $82.35 \pm 0.57^{\mathrm{c}^{* *}}$ & $104.86 \pm 0.15^{\mathrm{a}^{* *}}$ & $63.36 \pm 0.58^{\mathrm{d}^{* *}}$ \\
\hline Bakır (Cu) & $23.59 \pm 0.30^{\mathrm{e}^{* *}}$ & $35.07 \pm 0.01^{\mathrm{c}^{* *}}$ & $108.33 \pm 0.15^{\mathrm{a}^{* *}}$ & $33.18 \pm 0.02^{\mathrm{d}^{* *}}$ & $37.74 \pm 0.20^{\mathrm{b}^{* *}}$ \\
\hline Aluminyum & $4.69 \pm 0.08^{\mathrm{d}^{* *}}$ & $35.11 \pm 0.11^{\mathrm{a}^{* *}}$ & $22.86 \pm 0.11^{\mathrm{c}^{* *}}$ & $23.22 \pm 0.07^{\mathrm{b}^{* *}}$ & - \\
\hline Nikel (Ni) & $7.73 \pm 0.01^{\mathrm{c}^{* *}}$ & $11.26 \pm 0.06^{\mathrm{b}^{* *}}$ & $20.22 \pm 0.15^{\mathrm{a}^{* *}}$ & $9.34 \pm 0.08^{\mathrm{c}^{* *}}$ & $7.46 \pm 0.01^{\mathrm{d}^{* *}}$ \\
\hline Selenyum (Se) & $4.10 \pm 0.08^{\mathrm{a}^{* *}}$ & $0.97 \pm 0.04^{\mathrm{e}^{* *}}$ & $1.22 \pm 0.01^{\mathrm{d}^{* *}}$ & $2.10 \pm 0.01^{\mathrm{c}^{* *}}$ & $2.45 \pm 0.04^{\mathrm{b}^{* *}}$ \\
\hline Kurşun (Pb) & $60.60 \pm 0.55^{\mathrm{a}^{* *}}$ & - & - & $46.78 \pm 0.35^{\mathrm{b}^{* *}}$ & - \\
\hline $\operatorname{Krom}(\mathrm{Cr})$ & $11.00 \pm 0.03^{\mathrm{a}^{* *}}$ & - & - & - & $10.15 \pm 0.04^{b^{* *}}$ \\
\hline Lityum (Li) & - & $7.49 \pm 0.02^{\mathrm{a}^{* *}}$ & - & - & - \\
\hline Kadmiyum & - & - & $0.45 \pm 0.02^{\mathrm{a}^{* *}}$ & $0.14 \pm 0.01^{\mathrm{b}^{* *}}$ & - \\
\hline Kalay (Sn) & $1.68 \pm 0.01^{\mathrm{c}^{* *}}$ & - & - & $2.47 \pm 0.12^{\mathrm{b}^{* *}}$ & $2.91 \pm 0.01^{\mathrm{a}^{* *}}$ \\
\hline Civa (Hg) & - & - & - & $0.71 \pm 0.02^{\mathrm{a}^{* *}}$ & - \\
\hline Arsenik (As) & - & - & $0.04 \pm 0.00^{\mathrm{a}^{* *}}$ & - & - \\
\hline
\end{tabular}

Badem ezmelerinde potasyumdan sonra fosfor elementinin 19075.77-27418.58 $\mathrm{mg} \mathrm{kg}^{-1}$ yüksek miktarlarda bulunduğu tespit edilmiştir (Çizelge 3). Kandaki asit-baz reaksiyonunun dengelenmesinde rol alan fosfor, kalsiyum ile kemik bileşimini oluşturmakta ve vücutta meydana gelen reaksiyonlarda rol almaktadır (Saldamlı, 2005; Cemeroğlu, 2018).

Badem ezmesi örneklerinde ayrıca yüksek miktarlarda magnezyum (10146.04-15424.03 mg kg-1) ve kalsiyum elementinin (1260.82-2643.58 $\mathrm{mg} \mathrm{kg}^{-1}$ ) bulunduğu tespit edilmiştir (Çizelge 3). Sinirlerde elektriksel gerilimi sağlayan bir mineral olan magnezyumun günlük alım miktarı 280-350 mg olarak rapor edilmiştir (Jodral-Segado ve ark., 2003; Cemeroğlu, 2018). 100 g badem ezmesi tüketimi ile günlük alım miktarının 4-5 katı magnezyum vücuda sağlanmaktadır.

Ağır metal olan arsenik ve civa yalnızca birer örnekte düşük miktarda tespit edilmiştir (Çizelge 3). $\mathrm{Bu}$ duruma, bademlerin yetiştirilmesi veya badem ezmesi üretimi sırasında meydana gelen bulaşmanın sebep olduğu düşünülmektedir. Alüminyum, krom, mangan, nikel, bakır, çinko, kadmiyum, kalay ve kurşun düşük miktarlarda tespit edilmiştir (Çizelge 3). Cd, $\mathrm{Hg}, \mathrm{Pb}, \mathrm{Cu}$ ve As elementlerinin tespit edilen miktarları, zararlı dozların çok altındadır (Erdem, 2010; Özbolat ve Tuli, 2016)

Şimşek ve Kızmaz (2017) yaptıkları çalışmada, badem meyvesinde mineral madde olarak en yüksek miktarda (646.27-925.13 mg $100 \mathrm{~g}^{-1}$ ) potasyum ve fosforun (562.53-701.93 mg $100 \mathrm{~g}^{-1}$ ) bulunduğunu bildirmişlerdir. Yapılan çalışmalarda badem meyvesinin mineral içeriği miktarlarının potasyum 646.27-925.13 mg $100 \mathrm{~g}^{-1}$, fosfor 474.00-701.93 mg $100 \mathrm{~g} \mathrm{~g}^{-1}$, magnezyum 217.13-367.27 mg $100 \mathrm{~g}^{-1}$, kalsiyum 190.97-317.13 mg $100 \mathrm{~g}^{-1}$, sodyum $1.00-14.30 \mathrm{mg} 100 \mathrm{~g}^{-1}$, demir 4.30-10.28 mg 100 
$\mathrm{g}^{-1}$, çinko 3.36-9.33 mg $100 \mathrm{~g}^{-1}$, mangan 2.20-4.55 ve bakır 1.11-3.73 mg $100 \mathrm{~g}^{-1}$ olarak belirlendiği bildirilmiştir (Çapanoğlu, 2002; Şimşek ve Kızmaz, 2017).

Aslan (2019) bademlerde ağır metalleri tespit ettiği çalışmasında $0.007-0.058 \mathrm{mg} \mathrm{kg}^{-1} \mathrm{krom}$ 0.284-0.433 mg kg-1 mangan, 0.056-0.068 mg kg-1 nikel, 0.801-1.302 mg kg-1 çinko, 0.0004-0.0009 mg $\mathrm{kg}^{-1}$ arsenik, 0.0004-0.0013 mg kg-1 selenyum, 0.0009-0.014 $\mathrm{mg} \mathrm{kg}^{-1} \mathrm{kadmiyum}^{\mathrm{me}} 0.004-0.044 \mathrm{mg} \mathrm{kg}^{-}$ ${ }^{1}$ kurşun arasında tespit ettiğini bildirmiştir. Karcık (2017) yaptığı çalışmada bademde $\mathrm{Pb}, \mathrm{Hg}$ ve $\mathrm{Sn}$ elementlerinin tespit edilebilir düzeylerde bulunmadığını, kadmiyum (32.25-64.15 $\left.\mu \mathrm{g} \mathrm{kg}^{-1}\right)$, bakır (6.49$\left.8.90 \mathrm{mg} \mathrm{kg}^{-1}\right)$, nikel (0.10-0.84 mg kg${ }^{-1}$ ), çinko (18.23-31.02 mg kg-1), $\mathrm{krom}\left(348.6-861.9 \mu \mathrm{g} \mathrm{kg}^{-1}\right)$, demir (33.98-53.17 mg kg-1) ve arseniğin ise (2.06-2.33 $\mathrm{mg} \mathrm{kg}^{-1}$ ) yasal limitlerin altında tespit edildiğini bildirmiştir. Bademlerin mineral içerikleri çevresel faktörler, tarım uygulamaları, coğrafi konum, toprak bileşimi, su kaynağı, sulama rejimi, gübre bileşenleri, genotip ve bitki çeşidi gibi etkenlerle değişiklik göstermektedir (Şimşek ve Kızmaz, 2017).

\section{SONUÇ}

Edirne İli'nde geleneksel olarak üretilen ve Edirne İli'nin simgesi haline gelmiş olan badem ezmesinin bazı fizikokimyasal özellikleri, toplam fenolik madde içeriği ve antioksidan kapasitesi belirlenmiştir. $L^{*}, a^{*}$ ve $b^{*}$ değerlerine bakıldığında rengin açık sarıya daha yakın olduğu saptanmıştır. Badem ezmesinin protein içeriğinin yüksek olduğu ve protein kaynaği olarak tüketilebileceği düşünülmektedir. Sağlığa zararlı etkileri olan HMF yalnızca bir badem ezmesi örneğinde düşük miktarda tespit edilmiştir. Ayrıca badem ezmesi örneklerinin potasyum, fosfor, magnezyum ve kalsiyum bakımından zengin kaynak olduğu saptanmıştır. Badem ezmesi örneklerine ait toplam fenolik madde miktarı ve antioksidan aktivitesinin düşük olduğu belirlenmiştir. Badem ezmesinin besin değeri, toplam fenolik madde miktarı ve antioksidan aktivitesinin korunması için üretimde uygulanan işlemler standardize edilmelidir. Ayrıca fenolik madde miktarı ve antioksidan aktivitesi yüksek olan nutrasötik gıda katkıları kullanılarak, badem ezmesi içeriğinin zenginleştirilmesine yönelik üretim olanaklarının araştırılması gerekmektedir.

\section{Çıkar Çatışması}

Yazarlar arasında herhangi bir çıkar çatışması bulunmamaktadır.

\section{Yazar Katkısı}

Tüm yazarlar makaleye eşit oranda katkı sağlamıştır.

\section{KAYNAKLAR}

An J, Liu J, Liang Y, Ma Y, Chen C, Cheng Y, Peng P, Zhou N, Zhang R, Addy M, Chen P, Liu Y, Huang G, Ren D, Ruan R, Chen P, 2020. Characterization, bioavailability and protective effects of phenolic-rich extracts from almond hulls against pro-oxidant induced toxicity in Caco-2 cells. Food Chemistry, 126742.

Anonim, 2007. Trace elements $\mathrm{As}, \mathrm{Cd}, \mathrm{Hg}, \mathrm{Pb}$ and other elements. Determination by ICP-MS after pressure digestion. Nordic Committee On Food Analysis No:186, 14.

Aslan E, 2019. Siverek bölgesinde yetişen taze badem örneklerinin ağır metal, fenolik asit ve antioksidan içeriklerinin araştırılması, Batman Üniversitesi Fen Bilimleri Enstitüsü, Yüksek Lisans Tezi (Basılmış).

Aydin C, 2003. Physical properties of almond nut and kernel. Journal of Food Engineering, 60(3): 315-320.

Baiano A, Del Nobile MA, 2005. Shelf life extension of almond paste pastries. Journal of Food Engineering, 66(4): 487-495.

Bakla NS, 2018. Yüksek hidrostatik basınç ile geleneksel badem ezmesinin raf ömrünün uzatılması, Trakya Üniversitesi Fen Bilimleri Enstitüsü, Yüksek Lisans Tezi (Basılmış).

Balta MF, 2013. Fatty acid profiles for almond (Prunus amygdalus Batsch) genotypes with different kernel taste and formation. Iğdır University Jornal of the Institute of Science and Technology, 3(1): 17-24. 
Edirne’de Geleneksel Olarak Üretilen Badem Ezmesinin Bazı Kalite Özellikleri

Bardakçı Ö, 2017. Bazı Sentetik Antioksidanların 2,2-difenil-1-pikrilhidrazil (DPPH*) Radikal Süpürme Kapasitesi Yöntemi ile Antioksidan Aktivitelerinin Araştırılması, Adnan Menderes Üniversitesi Sağlık Bilimleri Enstitüsü, Yüksek Lisans Tezi (Basılmış).

Cemeroğlu BS, 2013. Gıda Analizleri. Bizim Grup Basımevi. Ankara, 480 s.

Cemeroğlu BS, 2018. Meyve ve Sebze İşleme Teknolojisi, Bizim Grup Basımevi. Ankara, 707 s.

Ciftci D, Ozilgen S, 2019. Evaluation of kinetic parameters in prevention of quality loss in stored almond pastes with added natural antioxidant. Journal of food science and technology, 56(1): 483-490.

Cunningham S, 1999. Confectionery pastes from almonds. Manufacturing Confectioner, 79: 66-74.

Çapanoğlu E, 2002. Badem ezmesinde kalite ve raf ömrünün iyileştirilmesi, İstanbul Teknik Üniversitesi Fen Bilimleri Enstitüsü, Yüksek Lisans Tezi (Basılmış).

Çiftci D, 2016. Antioxidant activity and mhibitory effects of black carrot aganst lipid oxidation in model food systems that are rich in mono and polyunsaturated fatty acids. Yeditepe University Institute of Health Sciences MSc Thesis (Printed).

Çilingir Yeltekin A, 2019. Eser elementler, ağır metaller ve analiz yöntemleri. Academic Studies in mathematıcs and natural sciences, 2: 83.

Er Ö, Bardakoğlu Ö, 2005. Kültürel mirasin sürdürülebilir turizm ürünü çeşidi olarak değerlendirilmesi: Edirne Örneği. Dokuz Eylül Üniversitesi İşletme Fakültesi Dergisi, 17(2): 95-111.

Erdem T, 2010. Ratlarda tek doz uygulanan kadmiyum toksikasyonunun patolojisi ve eş zamanlı uygulanan klorpromazinin koruyucu etkisinin araştırılması, Selçuk Üniversitesi Sağlık Bilimleri Enstitüsü, Doktora Tezi (Basılmış).

Esfahlan JA, Jamei R, Esfahlan JR, 2010. The importance of almond (Prunus amygdalus L.) and its by-products. Food Chemistry, 120: 349-360.

Faid M, Bakhy K, Anchad M, Tantaou1-Elarakı A, 1995. Almond paste: physicochemical and microbiological characterization and preservation with sorbic acid and cinnamon. Journal of food protection, 58(5): 547550.

Frison S, Sporns P, 2002. Variation in the flavonol glycoside composition of almond seed coats as determined by MALDITOF mass spectrometry. J. Agric. Food Chem., 50: 6818-6822.

Gulcin I, Oktay M, Kufrevioglu Öİ, Aslan A, 2002. Determination of antioxidant activity of lichen Cetraria İslandica (L) ach. Journal of Ethnopharmacology, 79: 325-329.

Harrison K, Were L, 2007. Effect of gamma irradiation on total phenolic content yield and antioxidant capacity of almond skin extracts. Food Chemistry, 102: 932-937.

Isfahlan AJ, Mahmoodzadeh A, Hassanzadeh A, Heidari R, Jamei R, 2010. Antioxidant and antiradical activities of phenolic extracts from Iranian almond (Prunus amygdalus L.) hulls and shells. Turkish Journal of Biology. 34: 165-173.

Jambazian PR, Haddad E, Rajaram S, Tanzman J, Sabaté J, 2005. Almonds in the diet simultaneously improve plasma $\alpha$-tocopherol concentrations and reduce plasma lipids. Journal of the American Dietetic Association, 105(3): 449-454.

Jodral-Segado AM, Navarro-Alarcón M, de la Serrana HLG, López-Martínez MC, 2003. Magnesium and calcium contents in foods from SE Spain: influencing factors and estimation of daily dietary intakes. Science of the total environment, 312(1-3): 47-58.

Karataş N, 2014. Farklı Kurutma Yöntemlerinin Bazı Kayısı Çeşitlerinin Kimyasal ve Fiziksel Özelliklerine Etkisi, Atatürk Üniversitesi Fen Bilimleri Enstitüsü, Doktora Tezi (Basılmış).

Karcık H, 2017. Çeşitli organik kuruyemişlerin ağır metal içeriklerine yönelik bir araştırma, Namık Kemal Üniversitesi Fen Bilimleri Enstitüsü, Yüksek Lisans Tezi (Basılmış).

King JC, Blumberg J, Ingwersen L, Jenab M, Tucker KL, 2008. Tree nuts and peanuts as components of a healthy diet. The Journal of Nutrition, 138(9): 1736-1740.

Kodad O, Estopañán G, Juan T, 2013. Protein content and oil composition of almond from Moroccan seedlings: genetic diversity, oil quality and geographical origin. Journal of the American Oil Chemists' Society, 90(2): 243-252. 
Kornsteiner M, Wagner KH, Elmadfa I, 2006. Tocopherols and total phenolics in 10 different nut types. Food chemistry, 98(2): 381-387.

Kurlandsky SB, Stote KS, 2006. Cardioprotective effects of chocolate and almond consumption in healthy women. Nutrition research, 26(10): 509-516.

Kurt A, Çakmakçı S, Çağlar A, 1999. Süt ve mamülleri muayene ve analiz metodları rehberi. Atatürk Üniv. Ziraat Fak. Yay. No:18, Erzurum, Türkiye, $238 \mathrm{~s}$.

Lin JT, Liu SC, Hu CC, Shyu YS, Hsu CY, Yang DJ, 2016. Effects of roasting temperature and duration on fatty acid composition, phenolic composition, Maillard reaction degree and antioxidant attribute of almond (Prunus dulcis) kernel. Food chemistry, 190: 520-528.

Lin X, Wu J, Zhu R, Chen P, Huang G, Li Y, Lin W, 2012. California almond shelf life: Lipid deterioration during storage. Journal of Food Science, 77(6): 583-593.

Luo MR, 2006. Applying colour science in colour design. Optics \& Laser Technology, 38: 392-398.

Monagas M, Garrido I, Lebrón-Aguilar R, Bartolome B, GómezCordovés C, 2007. Almond (Prunus dulcis (Mill.) DA Webb) skins as a potential source of bioactive polyphenols. J. Agric. Food Chemistry, 55: 8498-8507.

Özbolat G, Tuli A, 2016. Ağır metal toksisitesinin insan sağlığına etkileri. Arşiv Kaynak Tarama Dergisi, 25(4): $502-521$.

Pinelo M, Rubilar M, Sineiro J, Nunez M, 2004. Extraction of antioxidant phenolics from almond hulls (Prunus amygdalus) and pine sawdust (Pinus pinaster). Food Chemistry, 85: 267-273.

Polatoğlu B, 2013. Farklı yöntemler ile kurutulan kızılcık (Cornus mas L.) meyvesinin kuruma karakteristiklerinin incelenmesi, Atatürk Üniversitesi Fen Bilimleri Enstitüsü, Doktora Tezi (Basılmış).

Safarian S, Azarmi Y, Esfahlan AJ, Esfahlan HJ, 2016. The beneficial effects of almond (Prunus amygdalus Batsch) hull on serum lipid profile and antioxidant capacity in male rats. Turkish Journal of Medical Sciences, 46: 1223-1232.

Saldamlı İ, 2005. Gıda Kimyası, Ankara, Hacettepe Üniversitesi Yayınları, 587 s.

Sfahlan AJ, Mahmoodzadeh A, Hasanzadeh A, Heidari R, Jamei R 2009. Antioxidants and antiradicals in almond hull and shell (Amygdalus communis L.) as a function of genotype. Food Chemistry, 115(2): 529-533.

Şengül M, Erkaya T, Şengül M, Yildiz H, 2012. The effect of adding sour cherry pulp into yoghurt on the physicochemical properties, phenolic content and antioxidant activity during storage. International Journal of Dairy Technology, 65: 429-436.

Şimşek M, Kızmaz V, 2017. Determination of chemical and mineral compositions of promising almond (Prunus amygdalus L.) genotypes from Beyazsu (Mardin) region. International Journal of Agriculture and Wildlife Science (IJAWS), 3(1): 6-11.

Thomas B, 2001. Manual of dietetic Practice (3rd Ed.). Oxford: Blackwell Publishing.

Topdaş EF, 2018. Çaşırın (Ferula orientalis L.) Esansiyel Yağı ile Farklı Ekstraktlarının Antioksidan, Antimikrobiyal ve İn Vitro Nöroprotektif Aktivitelerinin Araştırılması, Atatürk Üniversitesi Fen Bilimleri Enstitüsü, Doktora Tezi (Basılmış).

Wijeratne SS, Amarowicz R, Shahidi F, 2006. Antioxidant activity of almonds and their by-products in food model systems. Journal of the American Oil Chemists' Society, 83(3): 223-230.

Yıldırım AN, Koyuncu F, Tekintaş E, Akıncı Yıldırım F, 2008. Isparta bölgesinde selekte edilen badem (Prunus amygdalus Batsch.) genotiplerinin bazı kimyasal özellikleri ve yağ asitleri kompozisyonları. ADÜ Ziraat Fakültesi Dergisi, 5(1): 19-25.

Yılmaz ÖM, 2011. Türkiye'de Yetiştirilen Başlıca Buğday Çeşitlerinin Antioksidan Aktivitelerinin ve Fenolik Asit Dağılımlarının Belirlenmesi ve Ekmeğin Nar Kabuğu Ekstraktı ile Zenginleştirilmesi, Ankara Üniversitesi Fen Bilimleri Enstitüsü, Doktora Tezi (Basılmış). 